\title{
PENJATAH PUPUK GRANULAR LAJU VARIABEL UNTUK TANAMAN JAGUNG
}

\section{(Variable Rate Granular Fertilizer for Corn Plants)}

\author{
Muhammad Tahir Sapsal ${ }^{1 *}$, Samsuar ${ }^{1)}$ \\ 1) Program Studi Keteknikan Pertanian Universitas Hasanuddin, Jl. Perintis Kemerdekaan km 10, Makassar \\ ${ }^{*}$ email korespondensi: tahirsapsal@gmail.com
}

\begin{abstract}
The need for corn has increased along with population growth. The increase in needs must of course be accompanied by an increase in corn production, one of which is by meeting the needs of plant nutrients during growth. In order to optimize plant growth, precision fertilization Need to be apply. However, the unavailability of precision fertilizer applicator for corn plants is an obstacle. This research is expected to be able to provide a precision rationing unit design for granular fertilizer in corn cultivation. The rationing unit is built using a $24 \mathrm{~V} 200 \mathrm{rpm}$ DC motor and is controlled using an Arduino mega module. Allotment uses a rotor with a volume of 26.52 $\mathrm{cm} 3$ / rotation. Control using PID. The fertilizer used is NPK fertilizer. The test results show that the system can control fertilizer rationing with a $96 \%$ determination coefficient. And able to aplly NPK fertilizer up to 2 tons / ha.
\end{abstract}

Keywords: NPK, metering device, corn, PID.

\begin{abstract}
ABSTRAK
Kebutuhan jagung mengalami peningkatan seiring dengan pertumbuhan penduduk. Peningkatan kebutuhan tersebut tentunya harus dibarengi dengan peningkatan produksi jagung, salah satunya dengan pemenuhan kebutuhan hara tanaman selama pertumbuhan. Perlu pengaplikasian pupuk yang sesuai dengan kebutuhan tanaman (pemupukan presisi) agar dapat mengoptimalkan pertumbuhan tanaman. Namun demikian belum tersedianya aplikator pemupukan presisi tanaman jagung menjadi kendala. Penilitan ini diharapkan mampu memberikan desain unit penjatah presisi untuk pupuk granular pada budidaya tanaman jagung. Unit penjatah dibuat menggunakan motor DC 24 V 200 rpm dan dikontrol menggunakan modul Arduino mega. Penjatahan menggunakan rotor dengan volume $26.52 \mathrm{~cm} 3 /$ rotasi. Pengontrolan menggunakan PID. Pupuk yang digunakan adalah pupuk NPK. Hasil pengujian menunjukkan bahwa system dapat mengontrol penjatahan pupuk dengan koefisien determinisasi sebesar $96 \%$. Dan dapat menjatah pupuk NPK hingga 2 ton/ha.
\end{abstract}

Kata Kunci: NPK, metering device, jagung, PID.

\section{PENDAHULUAN}

Pendahuluan diuraikan secara ringkas, lugas, dan jelas yang memuat latar belakang Kebutuhan jagung mengalami peningkatan seiring dengan pertumbuhan penduduk.
Selain sebagai bahan pangan, jagung juga memiliki peranan penting dalam industri agribisnis. Jagung digunakan sebagai bahan baku pakan ternak, khususnya ayam, yang dagingya merupakan sumber protein hewani. Sehingga dengan meningkatnya kebutuhan 
konsumsi daging ayam, juga mempengaruhi kebutuhan pakan ternak. Tahun 2016 sebanyak 2,4 juta ton jagung diimpor untuk kebutuhan pakan ternak, sementara tahun 2017, Kemenperin memperkirakan kebutuhan mencapai 14 juta ton (Kemenperin, 2017).

Peningkatan kebutuhan tersebut tentunya harus dibarengi dengan peningkatan produksi jagung. Berbagai upaya telah dilakukan dan terbukti mampu meningkatkan produksi, misalnya dengan penggunaan bibit unggul, pengendalian hama dan juga pemenuhan kebutuhan hara tanaman selama pertumbuhan.

Pemupukan merupakan kegiatan yang dapat dilakukan untuk meningkatkan kandungan hara tanah agar sesuai dengan kebutuhan tanaman. Namun demikian, saat ini, pengaplikasian pupuk masih diberikan secara seragam atau biasa disebut dengan metode URT (Uniform Rate Technology). Hal ini tentu mengakibatkan adanya respon dari tanaman yang berbeda, karena terdapat tanaman yang telah mendapatkan hara yang cukup dari tanah ada pula yang tidak, sehingga terjadi efek buruk terhadap tanaman yang mendapatkan hara yang berlebih maupun kekurangan. Tentu saja hal ini dapat mengurangi produksi dari tanaman. Disamping itu residu bahan kimia dari pupuk dapat berpengaruh buruk pada lingkungan. Diantaranya teracuninya air tanan, rusaknya kondisi tanah dan terjadinya pencemaran terhadap lingkungan sekitarnya.

Metode pemupukan presisi dapat membantu dalam menyelesaikan masalah rendahnya efisiensi pemupukan dan memberikan pengaruh besar dalam pengembangan pertanian berkelanjutan (Chen, 2013). Pemberian pupuk yang berimbang kepada tanaman jagung dapat memberikan produksi yang lebih tinggi dibandingkan dengan hanya memberikan pupuk yang berlebihan. Karena pemebrian pupuk berlebih tidak memberikan jaminan pada produksi tinggi, bahkan tidak menunjang efisiensi karena menambah biaya produksi (Tabri dan Rahmawati, 2013). untuk mengoptimalkan hal ini, tentu memerlukan ketelitian dan konsistensi dalam pemberian pupuk, sehingga dosis yang diberikan tepat/presisi. Penggunaan tenaga kerja tentunya harus mempertimbangkan hal tersebut. Namun adanya faktor kelelahan tentu dapat mempengaruhi kinerja, baik konsistensi maupun ketelitian pemberian, selain itu, agar dapat selesai tepat waktu untuk menghindari timeline cost tentu membutuhkan tenaga kerja yang banyak, apalagi jika diaplikasikan untuk lahan yang luas, sehingga diperlukan sebuah alat atau aplikator pupuk yang mampu memberikan dosis sesuai kebutuhan dan memiliki kapasitas kerja lebih besar dari tenaga kerja manusia.

Penerapan pertanian presisi merupakan praktek manajemen yang berpotensi meningkatkan keuntungan dengan memanfaatkan informasi yang lebih akurat tentang sumber daya pertanian (Rains dan Thomas, 2009). Keberadaan data merupakan aspek penting dalam penerapan pertanian presisi. Data tersebut dapat digunakan untuk menentukan tingkat aplikasi, pemilihan metode pembudidayaan, dan penjadwalan irigasi. Kendala penerapan system ini di Indonesia antara lain karena luasan lahan yang dimiliki petani. Sementara Manajemen pertanian presisi umumnya digunakan untuk pertanian skala besar karena mahalnya teknologi yang digunakan. Namun saat ini teknologi yang tersedia untuk mendukung aplikasi pertanian presisi telah berkembang dan dengan biaya yang terjangkau bagi petani. Untuk itu diperlukan peran peneliti untuk mengembangkan teknologi yang sesuai untuk mendukung kegiatan pertanian dan petani berdasarkan kemampuan finansial dari petani tersebut. Sehingga implementasi dari pertanian presisi untuk pertanian skala kecil dapat diterapkan, seperti penggunaan pupuk dan kapur dapat diterapkan hanya bila diperlukan, Pemilihan populasi jenis-jenis tanaman tanaman yang disesuaikan dengan kondisi tanah sehingga nutrisi tanah dapat dioptimalkan.

Pemanfaatan sistem kontrol dapat digunakan sebagai alternatif pemecahan masalah dalam mengontrol dosis pemupukan secara presisi. Sistem kontrol mengatur 
kecepatan putar penjatah (metering device) sehingga mampu memberikan penjatahan pupuk sesuai kebutuhan tanaman. Penjatahan pupuk presisi untuk tanaman padi, sebelumnya telah dikembangkan (Azis, 2011 dan Sapsal, 2015), yang mampu memberikan dosis pemupukan yang sesuai untuk tanaman padi serta hasil gabah yang dipanen memiliki keseragaman lebih dari $70 \%$ dan potensi penghematan pupuk hingga $13 \%$ (Gunawan 2013). Pada penelitian ini dikembangkan penjatah pupuk untuk tanaman jagung, yang dilengkapi dengan sistem kontrol, sehingga mampu memberikan dosis pemupukan yang presisi sesuai kebutuhan tanaman.

\section{Tujuan Penelitian}

Tujuan umum penelitian ini adalah mengembangkan alat pemupuk yang mampu memberikan dosis presisi yang dapat digunakan untuk budidaya tanaman jagung.

\section{METODOLOGI PENELITIAN}

\section{Alat}

Alat-alat yang digunakan dalam penelitian ini dikelompokkan ke dalam 2 bagian, yaitu;

- Alat konstruksi dan pemrograman: Alatalat bengkel (bor, gergaji, gurinda, dsb) dan, kabel downloader dan Perangkat komputer dengan Prosessor Intel Core i5, RAM 4 GB dengan OS Windows 1064 Bit.

- Alat Uji : Timbangan Digital DSP-425, Talang, USB to RS232.

\section{Bahan}

Bahan-bahan yang digunakan dalam penelitian ini dikelompokkan menjadi :

- Bahan konstruksi berupa : besi poros, akrilik, Motor DC 24 V 200 RPM, Modul Arduino Mega, Driver H-Bridge MOTOR DC 30A, Rotary Encoder 360 Pulsa, Arduino IDE. Serta komponen elektronik lainnya.

- Bahan Uji: Pupuk NPK.

\section{Prosedur Penelitian}

Penelitian ini meliputi kegiatan perancangan dan pengujian yang diuraikan sebagai berikut:

\section{Perancangan}

Disain unit penjatah yang digunakan disesuaikan dengan karakter pupuk pada pemupukan tanaman jagung, baik distribusi granular, higroskopisitas dan korosifitas terhadap bahan. Bagian utama dari unit penjatah berupa rotor, poros, rotary encoder, dan motor DC.

\section{a. Rotor}

Rotor terbuat dari bahan nilon dengan diameter 3 in. tinggi nilon $3 \mathrm{~cm}$ kedua ujung nilon dilubangi dengan lebar jari-jari $3.5 \mathrm{~cm}$, dengan jarak dari titik pusat 2.31 $\mathrm{cm}$ dan kedalaman $1 \mathrm{~cm}$ sehingga volume pupuk yang dapat ditampung sekitar 26.52 $\mathrm{cm} 3 /$ rotasi. lubang ini dibuat sebanyak 4 dengan fase sudut $30^{\circ}$ dibanding dengan lubang pada ujung yang lain.

b. Poros

Poros berupa stainless dengan diameter 1 $\mathrm{cm}$ dan panjang $15 \mathrm{~cm}$. stainless diplih karena lebih tanah terhadap karat.

c. Rotary encoder

Rotaray encoder yang digunakan untuk membaca jumlah putaran penjatah memiliki 360 pulsa dalam sekali putaran. Rotary encoder ini terpasang pada poros motor penggerak.

d. Motor DC

Penggerak poros rotor menggunakan motor DC dengan torsi besar bertegangan maksimum $24 \mathrm{~V}$ dengan putaran maksimum $200 \mathrm{rpm}$.

e. Hopper

Hopper yang berfungsi sebagai wadah penampung pupuk sebelum diteruskan ke unit penjatah berupa akrilik yang memiliki ketebalan $5 \mathrm{~mm}$. kelebihan dari akrilik yaitu kuat dan tidak berkarat. Pupuk yang digunakan yaitu pupuk NPK dengan sudut curah antara $31^{0}-35^{0}$, untuk itu, agar pupuk dapat jatuh ke metering device, maka kemiringan bagian bawah hopper dibuat dengan sudut $45^{\circ}$. 


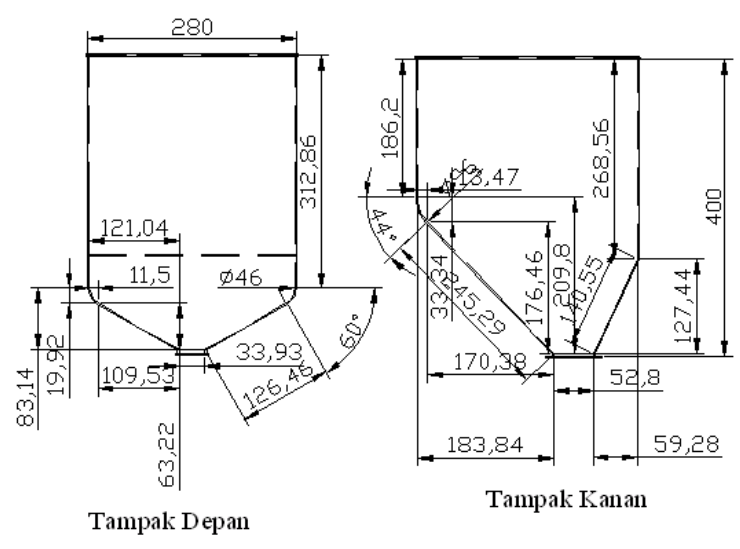

Gambar 1. Dimensi dan ukuran hopper

\section{Prosuder Pengujian}

Parameter yang diamati dalam penelitin ini berupa kemampuan pengontrolan motor dalam mencapai setpoint yang diberikan sehingga mampu memberikan laju keluaran pupuk yang linear terhadap perubahan frekuensi putaran motor. Sistem dijalankan pada frekuensi putaran 10, 20, 30 dan $40 \mathrm{rps}$, masing-masing selama 20 detik dan melihat massa pupuk yang dikeluarkan, dengan pengulangan 3 kali. Data yang diperoleh selanjutnya diplotkan ke dalam grafik hubungan antara rps.

\section{HASIL DAN PEMBAHASAN}

Penjatah pupuk dibuat berdasarkan rancangan dan dilakukan pabrikasi dan hasilnya dapat dilihat sebagai berikut :

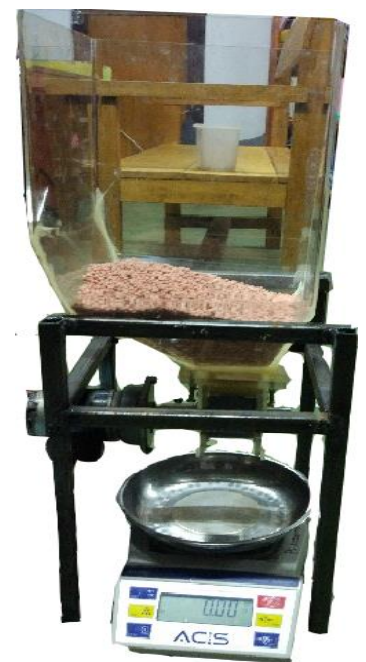

Gambar 2. Prototipe unit penjatah hasil rancangan
Motor yang digunakan adalah motor DC dengan tegangan input sebesar $24 \mathrm{~V}$. Pengujian dilakukan pada beberapa nilai PWM, motor mampu memberikan respon yang linear terhadap nilai PWM dengan nila R2 lebih dari 99\%. Hubungan antara penambahan nilai PWM dengan peningkatan kecepatan putaran motor dapat dinyatakan dengan persamaan $\mathrm{y}=2.8974 \mathrm{x}-3.1658$.

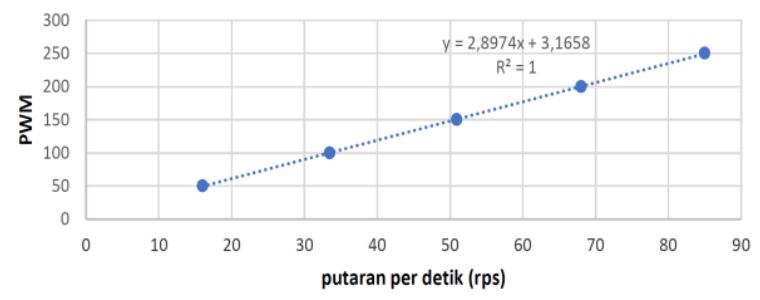

Gambar 3. Hubungan PWM dan putaran motor

\section{Tuning PID}

Nilai konstanta PID diperoleh dengan menggunakan metode tuning internal control karena metode ini memperhitungkan time sampling dalam pengontrolannya, sehingga hasil pengontrolan yang diberikan lebih baik dari Zeigler-Nichols (Setiawan et al. 2013).

Konstanta PID diperoleh dengan metoda least square dengan memplotkan kecepatan yang diperoleh dengan kecepatan (gambar 4). Adapun nilai konstanta yang diperoleh, berturut-turut untuk nilai $\mathrm{K}$, $\mathrm{T}$, dan d yaitu 2.9481, 0.0602, dan 0.0131.K yang diperoleh adalah 2.9481 .

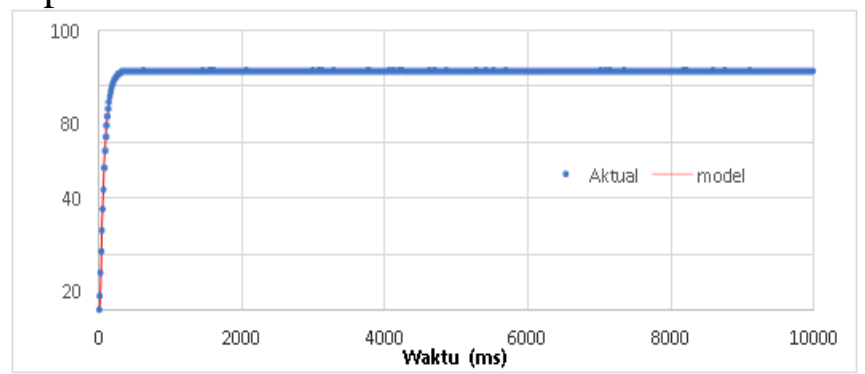

Gambar 4 Fitting nilai K, T dan d

Gambar diatas menunjukkan bahwa model dapat mengambarkan dengan tepat hasil pengukuran actual kecepatan motor.

\section{Pengujian kinerja Kontrol}

Kinerja dari kemampuan pengontrolan motor diuji menggunakan metode respon 
tangga (stair step) menggunakan nilai konstanta PID yang telah diperolah.

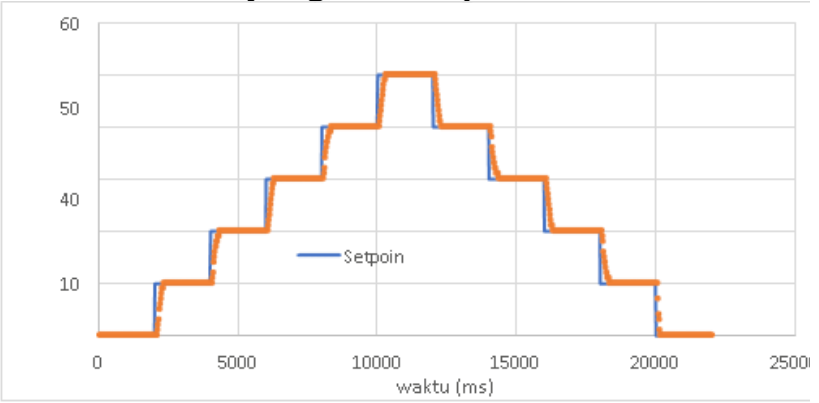

Gambar 5. Kecepatan motor berdasarkan setpoin yang diberikan

Gambar 5 menunjukkan bahwa kecepatan motor mampu menyesuaikan dengan setpoint yang diberikan, bukan hanya pada saat naik, tapi juga saat tangga turun. Tidak terjadi overshoot maupun undershoot pada perubahan setpoint. Hal ini berbeda dengan yang telah dilakukan oleh Sapsal 2015, dimana terjadi penyimpangan yang cukup besar saat terjadi perubahan setpoin. Hal ini disebabkan karena adanya perbedaan daya serta rpm motor, dimana motor yang digunakan dalam penelitian ini memiliki torsi yang lebih besar sehingga mampu mencapai setpoint tanpa terjadi penyimpangan yang terlalu besar. Namun demikian terjadi delay yaitu sekitar $280 \mathrm{~ms}$ atau 0.28 detik.

\section{Kinerja penjatahan pupuk}

Pengujian selanjutnya yaitu kemampuan penjatahan pupuk menggunakan penjatah yang telah terkontrol kecepatanya. Hal ini dilakukan untuk melihat hubungan antara frekuensi putaran motor dengan laju keluaran pupuk.

Hasil pengujian untuk melihat laju keluaran pupuk terhadap frekuensi putaran dapat dilihat Gambar 6.

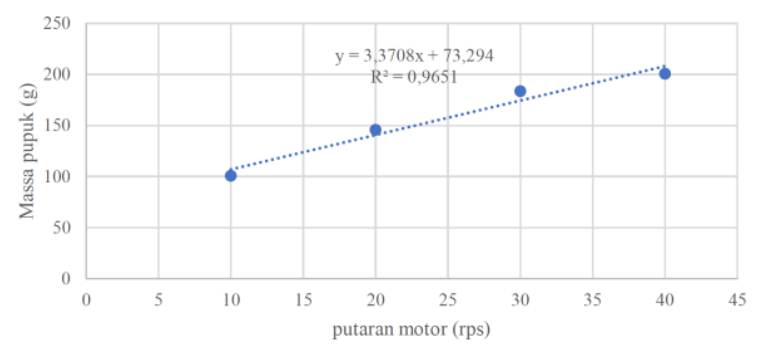

Gambar 6. Grafik hubungan kecepatan motor dengan keluaran pupuk.
Hasil yang diperoleh pada pengujian pupuk menunjukan bahwa penjatah mampu memberikan output pupuk linear dengan kecepatan motor, dengan koefisien determinasi lebih dari $96 \%$. Nilai ini lebih rendah dari hasil penelitian sapsal 2015. Hal ini disebabkan karena pada setpoin 40 rps rasio keluaran pupuk menurun. Penurunan laju keluaran pupuk ini dapat disebabkan karena perbandingan ukuran lubang hopper yang tidak mampu menyalurkan pupuk sebesar $26.52 \mathrm{~cm}^{3}$ atau lebih kecil dibandingkan dengan volume rotor. Sehingga, pada frekuensi putaran yang tinggi, saat motor telah bergerak, rotor belum terisi penuh. Namun demikian, penjatah pupuk tetap dapat memberikan penjatahan pupuk yang linear. Rata- rata keluaran pupuk perputaran, berturut-turut pada kecepatan 10, 20, 30, 40 rps adalah 10.07, 7.28, 6.12, dan 5.01 g/putaran. Dan berdasarkan grafik yang diperoleh, maka prototipe penjatah hasil rancangan mampu memberikan dosis penjatahan pemupukan hingga 2 ton/ha.

\section{KESIMPULAN}

Berdasarkan hasil pengujian diperoleh kesimpulan sebagai berikut :

1. Prototipe penjatah pupuk yang dirancang mampu memberikan output dosis pemupukan yang linear dengan kecepatan putar motor, dengan koefisien determinasi $96 \%$.

2. Semakin tinggi kecepatan motor semakin rendah rata-rata laju keluaran pupuk per putaran disebabkan karena ukuran rotor dan feeder pada wadah pupuk tidak sebanding.

3. Pengontrolan motor dengan menggunakan PID mampu memberikan pengontrolan yang baik sesuai dengan setpoint yang diberikan. 


\section{DAFTAR PUSTAKA}

Aziz A. (2011). Disain dan Pengujian Metering Device Untuk Unit Pemupuk Butiran Laju Variabel (Variable Rate Granular Fertilizer Applicator).Tesis. Sekolah Pascasarjana, Institut Pertanian Bogor.

Chen C, Pan J, dan Kee S.L (2013). A review of precision fertilization research. Environ Earth Sci 71:40734080.

Gunawan P. (2013). Pengembangan Prototipe Dan Uji Kinerja Mesin Pemupuk Dosis Variabel Pada Budidaya Padi Sawah Dengan Konsep Pertanian Presisi. Tesis. Sekolah Pascasarjana, Institut Pertanian Bogor.

Kementerian Perindustrian., 2017, RI impor jagung 2,4 juta ton, http://www.kemenperin.go.id/artikel/13 892/2016,-RI-Impor-Jagung-2,4-JutaTon [akses 20 januari 2020]

Rains G.C, dan Thomas D.L. (2009). Precision Farming: An Introduction. Bulletin the Cooperative Extension Service the University of Georgia College of Agricultural and Environmental Sciences 1186.

Sapsal, M.T, Setiawan, R.P.A, dan Hermawan, W. (2015). Desain Dan Pengujian Prototipe Mesin Pemupuk Butiran Laju Variabel. Jurnal AgriTechno, 8(1), 76-85.

Setiawan R.P.A, Tahir, M, Hermawan, W, dan Budiyanto, B. (2013). Mesin Pemupuk Presisi Laju Variabel Berbasis Mikrokontroler. Jurnal Teknotan 7(2).

Tabri F, Rahmawati. 2013. Pengkajian Pupuk Berimbang Terhadap Produksi F1 Calon Hibrida Umur Genjah Jagung Provit-A. Makalah Disampaikan pada Seminar Nasional Serealia, Maros Sulawesi Selatan 